\title{
Vitamin D status in Danish 9-month-old children
}

Østergård, Mathilde; Madsen, Anja Lykke; Michaelsen, Kim F.; Mølgaard, Christian

\section{Published in:}

Annals of Nutrition and Metabolism

DOI:

$10.1159 / 000248278$

Publication date:

2009

Document version

Publisher's PDF, also known as Version of record

Citation for published version (APA):

Østergård, M., Madsen, A. L., Michaelsen, K. F., \& Mølgaard, C. (2009). Vitamin D status in Danish 9-month-old children. Annals of Nutrition and Metabolism, 55(suppl. 1), 111. https://doi.org/10.1159/000248278 

DP2-03

EFFECTIVENESS OF ZINC SUPPLEMENTATION PLUS ORAL REHYDRATION SALTS COMPARED WITH ORS ALONE AS A TREATMENT FOR ACUTE DIARRHEA IN INFANTS AGED 1 TO 6 MONTHS IN A PRIMARY HEALTH CARE SETTING

Mazumder, Sarmila'; Bhandari, Nita'; Taneja, Sunita'; Dube, Brinda'; Agarwal, R. C.: Mahalanabis, Dilip; Fontaine, Olivierł; Black, Robert E. ; Bhan. Maharaj $\mathrm{K}$."

Society for Applied Studies, Delhi, IND; 'Badshah Khan Hospital, Haryana, IVI): Society for Applied Studies, Kolkata, IND; 'World Health Organization, Swit/crland, (HE; John Hopkins Bloomberg School of Public Health,

Maryland, USA; "Department of Biotechnology, New Delhi, IND

OB.JECTIVE: Touvaluate whether education and prov ision of zinc supplements 10 caregivers is effective in the treatment of acute diarrhea in infants aged 1 to 6) months.

NETHODS: Six clusters of 30,000 population were randomly assigned to intervention and control sites. Government, private providers, and village health workers were trained to prescribe zinc and ORS in diarrheal episodes in the intervention areas, and ORS alone in the control areas. Outcomes were measured in (wo cross-sectional surveys commencing 3 months (survey 2) and 6 months (survey 3) after the start of the intervention.

RESULTS: In the two surveys, zine was used in $36.7 \%$ and $62.1 \%$, and ORS in $30.1 \%$ and $61.1 \%$ of diarrheal episodes in the four weeks preceding interviews in the intervention areas compared to $4.7 \%$ and $8.8 \%$ in control areas. The 24 hour and 2-week prevalence of diarrhea and acute lower respiratory infections were lower in the intervention communities (survey 2 and 3 ).

CONCLUSIONS: Diarrhea in the first 6 months of life is effectively treated when caregivers receive education along with easy access to supplies of ORS and inc, without adversely affecting the use of ORS.

DP2-04

VITAMIN D STATUS IN DANISH 9-MONTH-OLD CHILDREN

()stergaard, Mathilde; Madsen, Anja L.; Michaelsen, Kim F.; Molgaard,

Christian

University of Copenhagen, Frederiksberg C, DNK

INTRODUCTION: Danish term infants are recommended vitamin D) supplement of $10 \mu \mathrm{g} /$ day on their first year. Objective To assess serum $25(\mathrm{OH}) \mathrm{D}$ in 9-month-old Danish children.

METHODS: The study is part of an observational cohort study (SKOT) following randomly selected term healthy children from age 9 to 36 months. All 312 (girls 163) Caucasian children, except for 10 mixed Caucasian-nonCaucasian, were examined at age 9 months. Serum 25(OH)D was assessed by chemiluminescence assay.

RESULTS: Weight and length were $9068 \pm 992$ gram (mean \pm SD) and $71.9 \pm 2.5$ $\mathrm{cm}$, respectively, 252 received vit D supplementation almost every day, 52 less often, and 8 were not supplemented. Serum 25(OH)D $(\mathrm{n}=255)$ was $77.2 \pm 22.7$ mmol/L (range: $12-151$ ). No significant sex difference $(p=0.37)$ was observed. Prevalence of severe vitamin D deficiency $(\leq 12.5 \mathrm{mmol} / \mathrm{L})$ was $0.4 \%(\mathrm{n}=1)$, deficiency $(\leq 37.5 \mathrm{mmol} / \mathrm{L}) 2.8 \%(\mathrm{n}=7)$, insufficiency $(37.5-50.0 \mathrm{mmol} / \mathrm{L}) 7.8 \%$ $(n=20)$ and sufficiency $(50-250 \mathrm{mmol} / \mathrm{L}) 89.4 \%(\mathrm{n}=228)$. There were higher levels in June-November $(n=107)$ than December-May $(n=148)(p=0.02)$. $81.2 \pm 21.9$ and $7+.3 \pm 22.8 \mathrm{mmol} / \mathrm{L}$, respectively.

CONCLUSION: Nearly all received vit D supplementation, and $89.4 \%$ had sufficient serum $25(\mathrm{OH}) \mathrm{D}$ ), however, there was an effect of season.

DP2-05

IRON-DEFICIENT RATS ARE MORE RESISTANT TO ZINC DEFICIENCY THAN IRON-ADEQUATE RATS

Kaganda, Joyceline E:

Tanzania Food and Nutrition Centre, I)ar fis Salaam. TLA

Different responses of rats to inc-deficient diets between iron-deficient and iron-adequate groups were determined. In Fxperiment I, forty-cight male rats received a diet of $25 \mu \mathrm{g} / \mathrm{n} / \mathrm{g}$ with either $40 \mu \mathrm{g} f \mathrm{e} / \mathrm{g}$ or $3.9 \mu \mathrm{g} / \mathrm{e} / \mathrm{g}$ diets for 21 days (stage 1). Thereafter, the same groups of rats were subjected to incdeficient $(<1 \mu g / g)$ dicts for $1+$ days (stage 2). Plasma, kidney and femur sinc concentrations decreased as sinc deficiency developed. Kidncy and femur zinc levels were significantly higher in iron-deficient than in iron-ade Blood and bone marrow amimolevulinic acid dehydratase $(A \mid A-1)$, IC and plasma alkaline phosphatase (ALK-P, E( $3.1 .3,1)$ activities decrease zinc deficiency in iron adequate group, however, in iron-deficient group

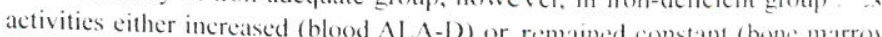
ALA-D and plasma ALK-P) throughout the experiment. In Experiment 2, the survival time after consuming rinc-deficient dicts $(<1 \mu g / g)$ was compare between rats fed iron-deficient and rats fed iron-adequate diets. The length o survival for iron-deficient group was longer $(1.33 \pm 17$ d) than the iron-idequat. group $(98 \pm 13 \mathrm{~d}),(\mathrm{p}<0.01)$. In Experiment 3, the influence of dictary iros levels $(2 \mu \mathrm{g} / \mathrm{g}, 13 \mu \mathrm{g} / \mathrm{g}$ or $40 \mu \mathrm{g} / \mathrm{g})$ on osmotic fragility of erythrocyte ank thiobarbituric acid-reactive substances (TBARS) in liver of rats fed either sinc deficient $(<1 \mu \mathrm{g} / \mathrm{g})$ or $/$ inc-adequate $(25 \mu \mathrm{g} / \mathrm{g})$ diets was examined. Although th osmotic tragility of erythrocyte and TBARS values in liver increased in sine deficient groups, rats fed with iron-adequate diets had higher hemolysis ane TBARS values than fow iron groups. These results suggest that iron-deficion rats are more resistant to zine deficiency than iron-adequate rats.

\section{DP2-06}

ASSESSMENT OF ANAEMIA AND IRON STATUS OF SCIOOL AGE CHILDREN (AGED 7-12 YEARS) IN RURAL COMMUNITIES OF ABIA STATE, NIGERIA

'Ignatius A Onimawo, Patricia O Ukegbu, Victoria U Asumugha, Julic L Anyika, Helen Okudu, Chinyere $A$ Echendu, Charles Nkwoala and Prosper Emebu

'Department of Biochemistry Ambrose Alli University PMB 14, Ekpoma Nigeria formerly of Human Nutrition and Dietetics, Michael Okpara Universit of Agriculture Umudike, N(iA

RATIONALE AND OBJECTIVES: Anemia is highly prevalent in developin countries and has been associated with various factors including iron deficiency malaria and worm infestation particularly among children. This stud investigated iron status of school children aged 7-12 years in rural communitic of Abia state, Nigeria.

METHODS: A total of 249 school children, 120 males and 129 Remales, age between 7-12 years, were used in the study. Hemoglobin, hematocrit, and serur ferritin were used to determine anemia and iron status. The subjects were als screened for malaria parasites and worm infestation to determine their impac on anemia. C-reactive protein (CRP) was used as an indicator of inflammatio or infection. Socioeconomic, anthropometric, body composition and dietar information were also collected from the children using standard methods.

RESULTS: The prevalence of anemia was $82.6 \%$, while iron deficiency wa $77.8 \%$. The average daily iron intake was estimated to be $30 \%$ below th recommended allowance. Malaria parasites and worm infestation were hig in the children $(93.2 \%$ and $41.8 \%$, respectively). Anemia was significantl associated with helminth infestation, malaria parasite, and CRP.

CONCLUSION: Generally the result of the study indicates that there was high prevalence of anemia, thus, there is need for malaria and helminths contro intervention in these communities.

\section{DP2-07}

EFFECT OF FOOD INTAKE ON CONCENTRATION OF ETHANOL AND MARKERS OF ETHANOL CONSUMPTION

Dierkes, Jutta'; Helmecke, Anne'; Westphal, Sabine²; Luley, Claus'; Jachau, Katja'; Borucki, Katrin

Medical Faculty. Magdeburg. DIU: University Magdeburg, Magdeburg. DEU

RATIONALE: Absorption of ethanol is influenced by the concurrent intake o food. It is, however, unknown whether urinary markers of ethanol consumption e.g. ethylglucuronide (I:T(j) or 5-hydroxytryptophol (HTOL), are alsi influenced by food intake.

METHODS: We perfomed a randomised study with I3 healthy male volunter $\left(26 \pm 3\right.$ years. $\left.13 \mathrm{MI} 24 \pm 3 \mathrm{~kg} / \mathrm{m}^{2}\right)$ who received either ethanol only $(0.7 \mathrm{~g}$ ethano per $h g$ body weight) or equal amounts of ethanol after a standardized breakfas (560 kcal). Blood ethanol concentration was measured in 15 min internals for 1 hours. Urinary ITC $\mathrm{i}$ and IITOL were measured for three days. The area unde the curre (AUC) was calculated.

RESULTS: The ALC of blood ethanel and I T i inere significantly lower atte 